\title{
Moving beyond classical markers of water quality: detection of enteric viruses and genotoxicity in water of the Sinos River
}

\author{
Bergamaschi, B. ${ }^{a}$, Rodrigues, MT. ${ }^{a}$, Silva, JVS. ${ }^{a}$, Kluge, M. ${ }^{a}$, \\ Luz, RB. ${ }^{a}$, Fleck, JD. ${ }^{a}$, Bianchi, E. ${ }^{b}$ Silva, LB. ${ }^{b}$ and Spilki, FR. ${ }^{a *}$ \\ aLaboratório de Microbiologia Molecular, Universidade Feevale, Rodovia RS-239, Km 2755, \\ CEP 93352-000, Novo Hamburgo, RS, Brazil \\ bLaboratório de Genotoxicidade, Universidade Feevale, Rodovia RS-239, Km 2755, \\ CEP 93352-000, Novo Hamburgo, RS, Brazil \\ *e-mail: fernandors@feevale.br
}

Received: May 24, 2013 - Accepted: August 22, 2013 - Distributed: May 31, 2015

\begin{abstract}
It is well recognized that the classical biological and chemical markers of environmental pollution do not necessarily indicate the presence or absence of emerging threats to public health, such as waterborne viruses and genotoxicants. The purpose of this preliminary study was to evaluate the presence of material of enteroviruses (EV), rotavirus (RV) and adenovirus (AdV) and genotoxicity in water samples from points of routine monitoring of water quality in the main course of the Sinos River. The points are classified into different levels of pollution in accordance to the Brazilian federal regulations. Viral genomes from EV, AdV were detected in two of the 4 collection points regardless of the level of urbanisation of the surrounding areas. In contrast, genotoxicity was not observed in piava (Leporinus obtusidens) fingerlings cultivated on these same water samples. Results were compared with classical physical, chemical and microbiological parameters. There was no clear evidence of association between any of the classical markers and the presence of viral genomes in the water samples tested.
\end{abstract}

Keywords: enteroviruses, rotavirus, adenovirus, genotoxicity, water quality.

\section{Indo além dos marcadores clássicos de qualidade da água: detecção de vírus entéricos e genotoxicidade na água do Rio dos Sinos}

\begin{abstract}
Resumo
É amplamente reconhecido que os marcadores biológicos e químicos clássicos para a poluição ambiental não necessariamente indicam a presença ou ausência de ameaças emergentes à saúde pública, tais como vírus transmitidos pela água e genotoxicantes. Este estudo preliminar teve por objetivo detectar material genético de enterovírus (EV), rotavírus (RV) e adenovírus (AdV) e genotoxicidade em amostras de água de pontos de monitoramento de rotina da qualidade da água no curso principal do rio dos Sinos. Os pontos são classificados em níveis diferentes de poluição, de acordo com as normativas federais brasileiras. Genomas virais de EV, RV e RV foram detectados em dois dos quatro pontos de coleta, independente do nível de urbanização das áreas adjacentes. Por outro lado, não foi observada genotoxicidade em alevinos de piava (Leporinus obtusidens) cultivados nestas mesmas amostras de água. Os resultados são comparados com marcadores físicos, químicos e microbiológicos clássicos, não há nenhuma evidência clara da associação entre qualquer um dos marcadores clássicos e da presença de genomas virais nas amostras de água testadas.
\end{abstract}

Palavras-chave: enterovírus, rotavírus, adenovírus, genotoxicidade, qualidade da água.

\section{Introduction}

The Rio dos Sinos basin accounts for $4.5 \%$ of the Guaíba watershed and occupies $1.5 \%$ of the area of the state of Rio Grande do Sul, Brazil. Human occupation along the river is variable: $90.6 \%$ of the $1,500,000$ inhabitants have local urban housing, and the remaining $9.4 \%$ live in rural areas. The upper reach of the river (Caraá to Rolante) has riparian vegetation and wetlands. Near the upper reach there are farms and agricultural areas where rice, vegetables and sugar cane are grown. In this area there are also pig, dairy and poultry farms. The middle reach of the river, between Taquara and Sapiranga, has lost proper rural characteristics. Population density is higher, but not near the riverbanks. In the lower reach, from Campo Bom to the source of the Jacuí Delta, the human population increases (Rio Grande do Sul, 2009). Thus, contamination and the spread of different pollutants, 
including enteric viruses and genotoxic compounds, may be expected to increase along the river from its source to the mouth (Table 1).

This study evaluated water quality at 4 points routinely monitored by local authorities using classical water quality markers, genotoxicological assays and molecular methods to detect genetic material of enteroviruses (EV, single-stranded positive sense RNA, family Picornaviridae, genus Enterovirus), rotavirus (RV, double-stranded segmented RNA, family Reoviridae, genus Rotavirus) and adenovirus (AdV, double-stranded DNA, family Adenoviridae, genus Mastadenovirus). Enteric viruses, such as EV, RV and $\mathrm{AdV}$, may be found in the environment as a consequence of fecal pollution and in surface waters (Hot et al., 2003; Vecchia et al., 2012). Analyses of genotoxicity in surface waters may help to diagnose environmental quality accurately. Among other cytogenetic techniques, number of nuclear abnormalities and micronuclei are good biomarkers of genotoxicity (Çavas and Ergene-Gozukara, 2003). The micronuclei technique is rapid and sensitive to detect structural changes, loss of DNA and chromosomal abnormalities (Heddle et al., 1983). This technique has been used to test fish samples in the monitoring of genotoxic effects of agents released into the environment (Bolognesi et al., 2002). This integrated diagnosis of environmental quality is highly needed in the Sinos River basin (Spilki and Tundisi, 2010).

\section{Material and Methods}

The collection points were numbered 1 to 4 . Point 1 , Caraá, is located close to the east end (Quebrada town). This stretch has little riparian vegetation and wetlands, a low population density, small farms and diversified agriculture (rice, sugarcane, vegetables, livestock, dairy cattle, pigs and

Table 1. Geographic coordinates and putative main contamination source in the selected sampling sites along the Sinos River.

\begin{tabular}{|c|c|c|}
\hline $\begin{array}{l}\text { Sampling } \\
\text { Point }\end{array}$ & Coordinates & $\begin{array}{c}\text { Main } \\
\text { contamination } \\
\text { source }\end{array}$ \\
\hline \#1 - Caraá & $\begin{array}{l}\text { S } 29^{\circ} 43^{\prime} 26^{\prime \prime} \\
\text { W } 50^{\circ} 16^{\prime} 46^{\prime \prime}\end{array}$ & $\begin{array}{c}\text { Minimal } \\
\text { anthropogenic } \\
\text { impact } \\
\text { Pig farms }\end{array}$ \\
\hline \#2 - Taquara & $\begin{array}{l}\text { S } 29^{\circ} 41^{\prime} 05^{\prime \prime} \\
\text { W } 50^{\circ} 50 \prime 52^{\prime \prime}\end{array}$ & $\begin{array}{l}\text { Agricultural } \\
\text { activities } \\
\text { Dairy and pigs }\end{array}$ \\
\hline $\begin{array}{c}\text { \#3 - Novo } \\
\text { Hamburgo }\end{array}$ & $\begin{array}{l}\text { S } 29^{\circ} 44^{\prime} 35^{\prime \prime} \\
\text { W } 51^{\circ} 07^{\prime} 45^{\prime \prime}\end{array}$ & $\begin{array}{l}\text { Metallurgical and } \\
\text { tannery industry } \\
\text { Urban areas } \\
\text { Urban effluents }\end{array}$ \\
\hline $\begin{array}{c}\text { \#4 - Sapucaia } \\
\text { do Sul }\end{array}$ & $\begin{array}{l}\text { S } 29^{\circ} 47^{\prime} 53^{\prime \prime} \\
\text { W } 51^{\circ} 11^{\prime} 24^{\prime \prime}\end{array}$ & $\begin{array}{c}\text { Metallurgical } \\
\text { industry } \\
\text { Urban effluents from } \\
\text { the metropolitan } \\
\text { area }\end{array}$ \\
\hline
\end{tabular}

poultry). Point 2, Taquara is located in the middle reach of the Sinos River, between Taquara and Sapiranga. In this stretch, population density is greater, but the two large cities in the region (Sapiranga and Taquara) are located far from the margins, and its characteristics are different from those of the upper reach. The main tributary of the Sinos in the middle reach is the Paranhana River, which drains the cities of Taquara, Igrejinha, Três Coroas and part of Gramado and Canela. Point 3, Novo Hamburgo (Gauchinho stream) is located in the lower reach of the Sinos River, from Campo Bom to its mouth in the Jacuí delta. This stretch is highly populated and industrial, and the main streams drain urban centers, such as Campo Bom (Schmidt stream) and Novo Hamburgo (Pampa stream and Luiz Rau stream). Point 4, Sapucaia do Sul (Balsa do Passo da Carioca) is located in the lower reach of the Sinos River, from Campo Bom to its mouth in the Jacuí delta. This stretch is highly populated and industrial, and the main streams drain large urban centers, such as Campo Bom (Schmidt stream), Novo Hamburgo (Pampa stream and Luiz Rau stream), São Leopoldo (João Correa stream) and Estância Velha and Portão (Portão stream / Estancia Velha).

Specimens of piava (Leporinus obtusidens), which belongs to the family Anostomidae, found along the River Plate system and in southern and southeastern Brazil (Hartz et al., 2000), were purchased from a grower in São Leopoldo. Specimens were acclimated for 24 hours in 9-litre tanks at the Laboratório de Citogenética, Universidade Feevale, under controlled conditions. After the acclimation period, the animals were exposed to water samples on the same day that collection was carried out. An aquarium was used for each collection point, and eight fish were exposed for 72 hours. An aquarium containing well water was used as a control.

After exposure, slides were prepared from peripheral blood. Blood was collected from a cut in the caudal region and dripped directly onto a clean and dry slide. Another slide at an angle of 45 degrees was used to spread the blood evenly and form a thin layer. After 10 minutes drying at room temperature, the slides were fixed in absolute methanol for 10 minutes and then stained with 5\% Giemsa diluted in phosphate buffer ( $\mathrm{pH}$ 6.8) for 10 minutes. The slides were then rinsed with distilled water and stored in boxes at room temperature for later analysis. One slide was prepared for each fish. Cytological analysis was performed under a light microscope (Nikon) with immersion lens (1000x). Two thousand (2000) intact erythrocytes were analysed in each fish sample (Al-Sabti and Metcalfe, 1995).

Nuclear changes were evaluated following the criteria described by Carrasco et al. (1990). Nuclei with abnormal morphology, membrane invagination and chromatin were classified as blebbed. Structures with a more significant invagination forming structures in the nucleus of erythrocytes were classified as lobed, and those with deep invaginations or gaps free of chromatin, as notched. Finally, nuclear targeting and bi-nucleation were also recorded. The nonparametric Kruskal-Wallis 
test was used for statistical analysis between groups, and the level of significance was set at $\mathrm{p}<0.05$.

Viral detection was conducted as described by Vecchia et al. (2012). Briefly, Water samples $(500 \mathrm{~mL})$ were collected aseptically, taken directly from the superficial water, in sterilised glass bottles. The samples were transported to the laboratory under refrigeration $\left(4^{\circ} \mathrm{C}\right)$, and were kept at this condition until sample concentration. Each $500 \mathrm{mLwater}$ sample was mixed with $0.3 \mathrm{~g} \mathrm{MgCl}_{2}$ and $\mathrm{pH}$ adjusted to 5.0 with $10 \% \mathrm{HCl}$. The resulting mixture was filtered through a type HA negatively charged sterile membrane (Millipore ${ }^{\mathrm{TM}}, 0.45 \mu \mathrm{m}$ pore size; $47 \mathrm{~mm}$ diameter). The membrane was rinsed with $87.5 \mathrm{~mL}$ of $0.5 \mathrm{mM}$ H2SO4 ( $\mathrm{pH} 3.0$ ), followed by elution of viral particles adsorbed to the membrane with $2.5 \mathrm{~mL}$ of $1 \mathrm{mM}$ $\mathrm{NaOH}$ ( $\mathrm{pH}$ 10.5). The filtrate was neutralized with $12.5 \mu \mathrm{L}$ of $50 \mathrm{mM} \mathrm{H} 2 \mathrm{SO} 4$ and $12.5 \mu \mathrm{L}$ of $100 \mathrm{x}$ Tris-EDTA (TE) buffer. The resulting mixture was aliquoted and stored at $-80{ }^{\circ} \mathrm{C}$ until further processing. Viral nucleic acids were extracted from $400 \mu \mathrm{L}$ of the concentrated sample using the RTP ${ }^{\circledR}$ DNA/RNA Virus Mini Kit (Invitek, Berlin, Germany) according to the manufacturer's instructions. The viral RNA or DNA so obtained was kept at $-80{ }^{\circ} \mathrm{C}$ until analysis.

For EV and RV, an additional step was performed before amplification, i.e. synthesis of cDNA, which was achieved with a High Capacity cDNA Reverse Transcription commercial kit (Applied Biosciences, USA), with the aid of random primers, following the manufacturer's instructions. Amplification was performed using a thermal cycler (MultiGene, Labnet International, USA). The PCR conditions were optimized for each virus group and were as follows: (a) $\mathrm{AdV}$ : $98^{\circ} \mathrm{C}$ for $7 \mathrm{~min}, 40$ cycles of $94^{\circ} \mathrm{C}$ for $1 \mathrm{~min}, 55^{\circ} \mathrm{C}$ for $1 \mathrm{~min}, 72^{\circ} \mathrm{C}$ for $1 \mathrm{~min}$; (b) $\mathrm{EV}: 98^{\circ} \mathrm{C}$ for $5 \mathrm{~min}, 35$ cycles of $94^{\circ} \mathrm{C}$ for $1 \mathrm{~min}, 56^{\circ} \mathrm{C}$ for $1 \mathrm{~min}$, $72{ }^{\circ} \mathrm{C}$ for $1 \mathrm{~min}$; (c) RV: $94{ }^{\circ} \mathrm{C}$ for $5 \mathrm{~min}, 40$ cycles of $94{ }^{\circ} \mathrm{C}$ for $1 \mathrm{~min}, 54^{\circ} \mathrm{C}$ for $1 \mathrm{~min}$ (which was decreased by $0.5^{\circ} \mathrm{C}$ at each of the 39 subsequent cycles), $72{ }^{\circ} \mathrm{C}$ for $1 \mathrm{~min}$. After cycles all reactions were left at $72^{\circ} \mathrm{C}$ for 7 minutes for final elongation. After the reactions, PCR products were stained with nontoxic fluorescent dye, Blue Green (LGCBio, Brazil), analysed by electrophoresis on $2 \%(\mathrm{w} / \mathrm{v})$ agarose gel and visualised under an ultraviolet (UV) light source.

\section{Results and Discussion}

The mean number of cells with micronuclei (MN) was not significantly different between sampling points and the control group $(p=0.77)$. Likewise, total nuclear abnormalities in erythrocytes of piava did not differ between groups $(p=0.80)$. The levels of segmented nuclei, binucleated cells and morphological nuclear changes classified as blebbed, lobed and notched were normal. Nuclear changes and micronucleus in the control fish $(2.9 \pm 3.8$ and $0.4 \pm 0.2)$ did not differ significantly from those found in fish exposed to the water collected from Point 1 (1.3 \pm 0.9 and $0.25 \pm 0.2)$, Point $2(0.7 \pm 0.6$ and $0.33 \pm 0.3)$,
Point $3(3.0 \pm 6.2$ and $0.25 \pm 0.3)$, or Point $4(1.3 \pm 1.65$ and $0.12 \pm 0.2)$.

Results are summarised in Table 2. EV and AdV were found in the water collected from the same site, Point 2. RV was detected in water collected from Point 4 (Sapucaia do Sul).

This study did not find any significant harmful effects of exposure of specimens of Leporinus obtusidens to water collected along the Sinos River. A possible explanation for the lack of genotoxicity may be the fact that water was collected during a flooding season, which may have resulted in the dilution of potential genotoxic substances (Ohe et al., 2004). In contrast, EV, RV and AdV genomes were found regardless of the anthropic occupation of the river margins (Table 2). Enteric viruses are highly resistant to the common practices of water treatment and disinfection, and may pose a threat to water quality (Hot et al., 2003; Lee. and Kim., 2002). It is noticeable that there was no relationship between the presence of viral genomes and genotoxicity. Viral genomes were found in the presence of higher levels of fecal coliform contamination, since they were absent for the Point 1 (29.4 MPN/100mL) and positive results were found in 2 other points $\left(10.1 \times 10^{3}\right.$ and $\left.53.8 \times 10^{3} \mathrm{MPN} / 100 \mathrm{~mL}\right)$.

Table 3 shows the physical and chemical parameters measured in each sample. Total phosphorus, aluminum and iron were found to be above the accepted levels by Brazilian federal regulations (Brasil, 2005). Total phosphorus may be associated with the presence of fecal pollution, such as fecal coliforms and enteric viruses. High levels of aluminum and iron may be a consequence of the release of these minerals into the environment from solid wastes, or solely or partially a result of the natural deposits of those minerals derived from the soil of the region.

This study points to the need to monitor the water of the Sinos River using complimentary analyses, such as virus detection and genotoxicity tests, in addition to the classical physical, chemical and microbiological markers. Those are validated by environmental agencies to ensure a higher level of safety for water quality; however, they did not necessarily ensure the safety of the water to emerging biological and chemical contaminants.

Table 2. Detection of Rotaviruses (RV), adenoviruses $(\mathrm{AdV})$ and enteroviruses (EV) in water samples collected from the Sinos River.

\begin{tabular}{lcccc}
\hline $\begin{array}{c}\text { Sampling } \\
\text { Point }\end{array}$ & RV & AdV & EV & $\begin{array}{c}\text { Fecal coliforms } \\
\text { (MPN*/100 } \mathbf{~ m L ) ~}\end{array}$ \\
\hline \#1 - Caraá & - & - & - & 29.4 \\
\#2 - Taquara & - & + & + & $1.01 \times 10^{3}$ \\
\#3 - Novo & - & - & - & $4.73 \times 10^{3}$ \\
$\begin{array}{l}\text { Hamburgo } \\
\text { \#4 - Sapucaia }\end{array}$ & + & - & - & $5.38 \times 10^{3}$ \\
do Sul & & & & \\
\hline
\end{tabular}

*most probable number. 
Bergamaschi, B. et al.

Table 3. Physical, chemical and microbiological parameters of water samples collected from four points of the Sinos River.

\begin{tabular}{|c|c|c|c|c|c|c|}
\hline Parameter & $\begin{array}{c}\text { Maximum } \\
\text { allowed } \\
\text { value }^{*}\end{array}$ & Unit & Point 1 & Point 2 & Point 3 & Point 4 \\
\hline $\begin{array}{l}\text { 01. Chemical demand of } \\
\text { oxygen }\end{array}$ & & $\mathrm{mgO} 2 \mathrm{~L}-1$ & 4 & 8 & 13 & 20 \\
\hline 02 Chlorides & 250 & mg L-1 & 3.6 & 3.6 & 4.7 & 5.5 \\
\hline 03.Conductivity & & mgCaCO3 L-1 & 26.2 & 58.6 & 75.4 & 82.5 \\
\hline 04.Hardness & & mg L-1 & 5 & 16 & 18 & 20 \\
\hline 05.Total Nitrogen & & mg L-1 & $<0.5$ & $<0.5$ & $<0.5$ & $<0.5$ \\
\hline 06.Ammonia Nitrogen & 3.7 & mg L-1 & $<0.5$ & $<0.5$ & $<0.5$ & $<0.5$ \\
\hline 07. Total Phosphorus & 0.1 & mg L-1. & n.d. & 0.061 & 0.195 & 0.274 \\
\hline 08.Aluminum & 0.1 & mg L-1 & 0.07 & 0.96 & 0.88 & 1.39 \\
\hline 09.Lead & 0.01 & mg L-1 & n.d. & n.d. & n.d. & n.d. \\
\hline 10.Chromium & 0.05 & mg L-1 & n.d. & n.d. & n.d. & n.d. \\
\hline 11.Copper & 0.009 & mg L-1 & 0.001 & 0.003 & 0.004 & 0.006 \\
\hline 12.Nickel & 0.025 & mg L-1 & 0.01 & 0.008 & 0.01 & 0.01 \\
\hline 13.Iron & 0.3 & L-1 001 & 0.05 & 1.14 & 1.30 & 1.48 \\
\hline 14. Zinc & 0.18 & mg L-1 & n.d. & 0.004 & 0.028 & 0.006 \\
\hline 15. Sodium & & mg L-1 & 2.7 & 5.1 & 2.3 & 6.4 \\
\hline 16.Dissolved Solids & & mg L-1 & 38.0 & 55.0 & 36.0 & 73.0 \\
\hline 17. Total Solids & 500 & - & 134 & 202 & 101 & 216 \\
\hline 18.Total Volatile Solids & & mg L-1 & 89.0 & 126 & 65.0 & 78.0 \\
\hline 19. pH & & mg L-1 & 6.80 & 7.05 & 7.03 & 6.72 \\
\hline 20. nitrate & 10.0 & mg L-1 & n.d. & 0.25 & 0.08 & 0.32 \\
\hline 21. Nitrite & 1.0 & mgCaCO3 L-1 & n.d. & 0.01 & 0.03 & 0.04 \\
\hline 22.Dissolved Oxygen & & $\mathrm{mgO} 2 \mathrm{~L}-1$ & 9.40 & 8.18 & 6.13 & 5.92 \\
\hline 23.Total Coliforms & & mg L-1 & 1296 & $124.6 \times 10^{2}$ & $344.1 \times 10^{2}$ & $396.8 \times 10^{2}$ \\
\hline $\begin{array}{l}\text { 24.Fecal Coliforms } \\
\text { (Escherichia coli) }\end{array}$ & $\begin{array}{c}\text { Absence in } \\
100 \mathrm{ml}\end{array}$ & $\mathrm{MPN} / 100 \mathrm{~mL}$ & 29.4 & $10.1 \times 10^{3}$ & $47.3 \times 10^{3}$ & $53.8 \times 10^{3}$ \\
\hline
\end{tabular}

nd: not detected. *CONAMA (Brasil, 2005) and FEPAM (Rio Grande do Sul, 2009).

\section{References}

AL-SABTI, K. and METCALFE, CD., 1995. Fish micronuclei for assessing genotoxicity in water. Mutation Research, vol. 343, no. 2-3, p. 121-135. http://dx.doi.org/10.1016/0165-1218(95)900780. PMid:7791806.

BOLOGNESI, C., PERRONE, E. and LANDINI, E., 2002. Micronucleus monitoring of a floriculturist population from western Liguria, Italy. Mutagenesis, vol. 17, no. 5, p. 391-397. http://dx.doi.org/10.1093/mutage/17.5.391. PMid:12202626.

Brasil. Conselho Nacional Do Meio Ambiente - CONAMA, 2005. Resolução CONAMA 357, de 2005. Dispõe sobre a classificação dos corpos de água e diretrizes ambientais para o seu enquadramento, bem como estabelece as condições e padrões de lançamento de efluentes, e dá outras providências. Diário Oficial da União, Brasília, 18 mar, p. 58-63. Available from: < http://www.mma.gov.br/port/conama/res/res05/res35705.pdf>. Access in: 22 Feb. 2013.

CARRASCO, KR., TILBURYT, KL. and MAYERS, MS., 1990. Assessment of the piscine micronuclei test as in-situ biological indicator of chemical contaminant effects. Canadian Journal of Fisheries and Aquatic Sciences, vol. 47, no. 11, p. 2123-2136. http://dx.doi.org/10.1139/f90-237.
ÇAVAS, T. and ERGENE-GÖZÜKARA, S., 2003. Micronuclei, nuclear lesions and interphase silver-stained nucleolar organizer regions (AgNORs) as cyto-genotoxicity indicators in Oreochromis niloticus exposed to textile mill effluent. Mutation Research, vol. 538, no. 1-2, p. 81-91. PMID: 12834757

HARTZ, SM., SILVEIRAT, CM., CARVALHO, S. and VILLAMIL, C., 2000. Alimentação da piava, Leporbzus obtusidens (Characiformes, Anostomidae), no Lago Guaíra, Porto Alegre, Rio Grande do Sul, Brasil. Pesquisa Agropecuária Gaúcha, vol. 6, no. 1, p. 145-150.

HEDDLE, JA., HITE, M., JRKHART, B., MAVOURNIN, K., MACGREGOR, JT., NEWELL, GW and SALAMONE, MF., 1983. The indroduction of micronuclei as a measure of genotoxicity. A report of the U.S. Environmental Protection Agency Gene-Tox Program. Mutation Research, vol. 123, no. 1, p. 61-118. http:// dx.doi.org/10.1016/0165-1110(83)90047-7. PMid:6888413.

HOT, D., LEGEAY, O., JACQUES, J., GANTZER, C., CAUDRELIER, Y., GUYARD, K., LANGE, M. and ANDRÉOLETTI, L., 2003. Detection of somatic phages, infectious enteroviruses and enterovirus genomes as indicators of human enteric viral pollution in surface water. Water Research, vol. 37, no. 19, p. 4703-4710. http:// dx.doi.org/10.1016/S0043-1354(03)00439-1. PMid:14568057.

LEE, SH. and KIM, SJ., 2002. Detection of infectious enteroviruses and adenoviruses in tap water in urban areas in Korea. Water 
Research, vol. 36, no. 1, p. 248-256. http://dx.doi.org/10.1016/ S0043-1354(01)00199-3. PMid:11766801.

OHE, T., WATANABE, T. and WAKABAYASHI, K., 2004. Mutagens in surface waters: a review. Mutation Research, vol. 567, no. 2-3, p. 109-149. http://dx.doi.org/10.1016/j.mrrev.2004.08.003. PMid:15572284.

Rio Grande do Sul. Fundação Estadual de Proteção Ambiental Henrique Luiz Roessler - FEPAM, 2009. Qualidade das águas da bacia hidrográfica do Rio dos Sinos. FEPAM. Available from: $<$ http://www.fepam.rs.gov.br/qualidade/qualidade_sinos/sinos. asp>. Access in: 25 Mar. 2009.

SPILKI, FR. and TUNDISI, JG., 2010. Priority targets for environmental research in the Sinos River basin. Brazilian
Journal of Biology= Revista Brasileira de Biologia, vol. 70, no. 4, supplement, p. 1245-1247. http://dx.doi.org/10.1590/S151969842010000600014. PMid:21225166.

VECCHIA, AD., FLECK, JD., COMERLATO, J., KLUGE, M., BERGAMASCHI, B., SILVA, JV., LUZ, RB., TEIXEIRA, TF., GARBINATTO, GN., OLIVEIRA, DV., ZANIN, JG., VAN DER SAND, S., FRAZZON, APG., FRANCO, AC., ROEHE, PM. and SPILKI, FR., 2012. First description of adenovirus, Enterovirus, rotavirus and torque teno virus in water samples collected from the Arroio Dilúvio, Porto Alegre, Brazil. Brazilian Journal of Biology $=$ Revista Brasileira de Biologia, vol. 72, no. 2, p. 323329. http://dx.doi.org/10.1590/S1519-69842012000200013. PMid:22735140. 